\title{
CHANGES IN TRANSITIONS FROM PRIVATE RENTING TO HOMEOWNERSHIP IN THE CONTEXT OF RAPIDLY RISING HOUSE PRICES
}

\author{
Paul Sissons \\ Centre for Business in Society \\ Coventry University \\ paul.sissons@,coventry.ac.uk \\ Donald Houston \\ Department of Geography \\ Portsmouth University \\ donald.houston@port.ac.uk
}

\begin{abstract}
A period associated with the emergence of the current housing crisis in Britain provides a testbed in which to investigate household tenure choice in the context of rapidly rising house prices. We compile a bespoke dataset combining data from the British Household Panel Survey and sources of local and national housing and mortgage market information covering the period 1994-2008. During this period, we observe three key changes in behaviour associated with the emergence of the housing crisis: i) increasing acceptance of long-term renting; ii) the emergence of local house prices as a factor inhibiting entry to homeownership at district level; and iii) the cessation of moving to a lower cost district as a strategy to enter homeownership. We interpret these findings as some private tenants reducing their aspiration for homeownership, and those seeking entry to homeownership shifting strategy from moving to cheaper districts in favour of staying put and saving.
\end{abstract}

Keywords: private rented housing, housing tenure, housing choice, Great Britain 


\section{Introduction}

The contraction of owner occupation in Great Britain since the beginning of the twenty-first century has been linked to delayed entry to home ownership, with the average age of a first-time home purchaser rising and corresponding rising durations of time spent renting privately. The 'generation rent' narrative in Britain emphasises the increasing unaffordability of home ownership as the main factor driving rising durations of time spent in the private rented sector (PRS). Concerns have been expressed about the displacement of low-income, and increasingly also middle-income, segments of the population from high-cost locations, particularly London and some other cities, as housing becomes unaffordable to buy and rental alternatives often do not offer security or quality. Nevertheless, more landlords than in the past see the PRS as a long-term investment which has led to some improvements in quality and security (Crook and Kemp, 2011), which may make the tenure more attractive as a long-term home. In parallel, homeownership itself may be becoming somewhat less attractive to young adults than in the past beyond the effects of affordability, for example due to the increased desirability of urban living and reductions in residential movements out of cities to suburban locations (Champion and Brown, 2012), which have traditionally been associated with entry to homeownership linked to broader mutability of lifestyles and employment.

This paper extends current understandings of the evolution of the British housing market by assessing changes in the transition from private renting to homeownership during Britain's long boom. The empirical analysis is focused in particular on the following three questions. First, whether rising house prices are restricting access to homeownership in high-cost districts. Second, whether rising durations in the PRS reflect preferences shifting in favour of renting. Third, whether residential mobility (to more affordable districts) is playing an increasing role in facilitating homeownership.

The analysis is focused on change during the 1990s and 2000s (1994-2008). This was an important period in the evolution of the British housing market as prices began to accelerate sharply, representing the early period of what is now widely described as a housing crisis. The evolution of house prices is presented in Figure 1 which tracks average house prices (adjusting for inflation) between 1991 and 2013. These show a sharp upturn at the start of the 2000s, which continued until 2007. Of particular relevance to this analysis, house prices grew approximately twice as quickly in later period of study (2001-2008) as in the former (1994-2000). Within overall accelerating house price growth, regional patterns of speed of growth differ over this period, with house price rises in London being particularly large. The period covered by the analysis is 
also the time during which patterns of tenure began to change and the long-run historical decline in importance of the PRS went into reverse, marking the start of a distinct shift (Houston and Sissons, 2012). Yet there has been relatively little attention played to the changing nature of the PRS in housing pathways that occurred over this critical period.

Figure 1 Here

Rapid house price inflation has re-emerged in buoyant parts of Great Britain in recent years. Although this is yet to become re-established in many locations housing affordability remains a critical issue. The period since the financial crisis of 2008 is marked by a fall and subsequent rise in house prices and very different mortgage lending conditions. This period is therefore excluded from the analysis, which is focused on the implications for the transition from renting to owning in the context of rapidly rising house prices. The period preceding the financial crisis also has the added advantage of preceding significant divergence in housing policy between the devolved administrations across the UK (Northern Ireland, Scotland and Wales).

This analysis is of significance beyond Great Britain in aiding understanding of the influence of duration, cost and mobility on housing tenure and location choice. Many advanced economies have experienced significant house price inflation (particularly concentrated in cities), the study provides learning about choice and mobility which will have resonance elsewhere as the social and economic influences on housing pathways become more complex.

\section{Becoming a homeowner, residential mobility and the lifecourse}

This paper focuses on three factors that altered significantly during the long economic boom in Britain: durations in the private rented sector (which have risen); house prices (which have risen); and residential mobility (which has fallen overall).

A number of literatures inform what is known about the transition from renting to owning a home. Tenure choice literature has identified that household income, the relative costs of different tenures and expected length of residence are strongly associated with entries to homeownership (Di Salvo and Ermisch, 1997). Rapidly rising house prices for purchase in Britain during the long boom could therefore be expected to have reduced transitions from renting to owning (question 1). 
Experience of a given housing tenure in the past affects future propensity to remain in or reenter that tenure (Di Salvo and Ermisch, 1997). There are a number of reasons to assume that renters may increasingly opt to remain a in the PRS for longer. In Britain, the average age of a first-time buyer has increased (Kemp, 2015), meaning migration rates are likely to decline (as mobility declines with age (Clark, 2012)), more renters than before will have put down roots (e.g. children starting at a local school) and would reach state retirement age before the end of a standard 25-year mortgage term should they become an owner-occupier. Increasing numbers of investment landlords entering the PRS in Britain, not least financed through the expansion of Buy-To-Let mortgages, may have improved security and quality in the PRS (Crook and Kemp, 2011) - meaning that tenants may be more inclined than in the past to come to the view that their current landlord offers an acceptable levels of security and property maintenance. Therefore, it could be expected that the growth of private renting in Britain may in itself serve to over time increase the propensity of individuals and households over time to choose private renting (question 2).

Residential mobility research has identified a number of triggers to local moves, including the desire to become a homeowner (Clark, 2012). High house prices could be expected to either increase or decrease residential mobility, depending on the availability of cheaper housing for purchase in surrounding areas. Conversely, a desire to make counterurbanising moves from city to suburb or exurbia may drive entries to homeownership in order to secure suitable accommodation in such locations. Rising prices in previously affordable places, overall reductions in residential mobility (Champion and Shuttleworth, 2017) and slowing urban-to-rural migration (Champion and Brown, 2012) could all be expected to have reduced the link between entry to homeownership and moving to lower housing cost areas (question 3).

A variety of lifecourse-related research, including studying: leaving the parental home; entering the labour market; partner formation; having children; divorce/separation; and retirement often considers how housing situation, including tenure, shapes these choices, particularly their timing (Bitter and Plane, 2012). Fourth, the concept of the 'housing career' has been used to examine the implications of such life events for the housing situation of individuals and households, alongside the opportunities and constraints presented by the local housing system and how these relationships are mediated by socio-economic factors (van Ham, 2012). Housing decisions are closely linked to lifecourse and housing availability and may recursively affect lifecourse-related decisions such as getting married (Mok, 2005). Demographic factors are therefore included in our analysis as controls. 
Expectations about the future are also important in shaping housing choices (Chung and Haurin, 2002; Zhou, 2011). Expectations relate to future household incomes and security of income, anticipated future rises to house prices and mortgage costs (Di Salvo and Ermisch, 1997; Zhou, 2011). Those who anticipate being able to afford homeownership in the future may opt to rent privately or remain with parents on a semi-temporary basis until such time as they can secure a mortgage. Similarly, those who do not anticipate being able to afford homeownership in the future may opt to rent privately, remain with parents or live in temporary accommodation (e.g. hostels, caravans). Expectations of future, and prevailing current, mortgage market conditions are therefore included in our analysis as controls.

\section{An evolving housing system in Britain}

There are broadly three main housing tenures available in Britain - homeownership, private renting and social renting. Access to homeownership is determined mainly by ability to borrow mortgage-based finance and liquid assets available for a downpayment or 'deposit' (Jones, 1995). The two rental sectors in Britain are distinct, with substantially higher rents and only fixed-term tenancies available in the private sector in most parts of the Britain - meaning that in practice the social and private rented sectors effectively operate as separate housing tenures (Kemeny, 1995). The social rented sector offers subsidised rent and greater security of tenure, but choice of property and location is limited, waiting lists are long and access depends on being in priority need (Malpass and Murie, 1999). The private rented sector offers flexibility, but security of tenure is low and properties are often not of modern standards (Rhodes, 2006).

Britain saw a large expansion of home ownership throughout the second half of the twentieth century, which for some time now has been the dominant form of housing tenure to which the majority of households aspire. However, the proportion of households in homeownership has contracted since the early 2000s.

The private rented sector (PRS) in Britain began growing around 1990, just as the growth rate in homeownership slowed, suggesting a degree of substitution as more households began to rent for longer before opting to buy (Houston and Sissons, 2012). Similarly, growth in the PRS accelerated during the new millennium, as the proportion of home owners went into decline, again suggesting a link between the two. By 2015, the PRS accounted for around one-fifth of all households in England (DCLG, 2016) 
Both survey and qualitative research evidence suggests a continuing strong attachment to the notion of property ownership even as it has become increasingly expensive (Hoolchan et al, 2017). Responses to the British Social Attitude Survey demonstrate a high and consistent preference for home ownership; 86 per cent of respondents in 2010 stated a 'theoretical preference for home ownership', which is consistent with previous years (Bramley, 2012; 132). Although when asked about the advice the respondent would give to a 'newly-married young couple' the preference to 'wait a bit, then try to buy a home' did increase during the latter half of the 2000s, indicating an underlying preference for owner-occupation but an increasing willingness to delay entry to homeownership.

Although in this paper we discuss findings across Great Britain as whole, it is important to note that the process of devolution in Britain is creating a 'divergence in housing policy' between nations, particularly affecting both the social and market rented sectors (McKee et al, 2017; 60). The period we analyse is one of early movements towards devolution, with the divergence in housing policy becoming more pronounced since 2010 (McKee et al, 2017). In the future it will be important for research to address the (national) impacts of these differentiated housing policies.

Along with many other post-industrial economies, Britain displays sharp and rising geographical contrasts in economic prosperity, employment prospects and housing costs. Particularly since the late 1980s, London and the southeast have grown markedly faster than the rest of Britain, and housing costs in the capital have led to an outward displacement of lower and middleincome households (Atkinson, 2000; Hamnett, 2003; Maclennan and Chowdhury, 2014). Net internal migration, traditionally from the peripheral north to the more prosperous south, has reversed since the early 1990s in favour of the north, partly due to the cost of housing in London but also because of increased competition for jobs from international migrants in London (Hatton and Tani, 2005).

On the one hand, high house prices in London and the southeast act as a stronger deterrent to homeownership. On the other hand, anticipated capital gains from future house price appreciation increase the long-run gains from homeownership relative to renting (Muellbauer and Murphy, 1997; Hatton and Tani, 2005). Further, mortgage lenders are more liberal in buoyant housing markets because the costs of default are lower for the lender - meaning home buyers may be able to obtain higher loan-to-value and loan-to-income ratios in buoyant regional housing markets (Ranney, 1981). Consequently, the growth of the PRS is intertwined with the 
UK's imbalanced economic geography and evolving international and internal migration patterns.

\section{Methods and data}

Research design and scope

To examine the whether the nature of transitions between the PRS and owner-occupation has changed over time we estimate a model including factors which the literature suggests may influence flows from the PRS into owner-occupation. We focus on three main phenomena which may have changed the relationship between the two tenures over the past two decades: the rapid rise of house prices; the association between rising duration in the PRS and reduced exits to owner-occupation; and the role of geographic mobility, in particular inter-district movements to cheaper locations - while controlling for the fundamentals of tenure choice already established in the literature. The analysis uses data from a longitudinal study of households - the British Household Panel Survey (BHPS) - augmented with temporal and spatial data on housing and mortgage market conditions.

To examine the factors associated with exiting the PRS for owner-occupation, and whether these changed between the 1990s and the 2000s, we estimate logit models with random-effects for two time periods: i) 1994-2000; ii) 2001-2008. We make a direct comparison of models i) and ii) to compare how the determinants of tenure choice changed in Britain between the 1990s and the 2000s. This timespan includes: a period of steady growth in private renting and homeownership and steadily rising house prices (1994-2000); and a period of declining homeownership and rapidly rising house prices (2001-2008). In the earlier years of the period (1994-2000) individuals had on average a 13.5 per cent chance of moving into owner-occupation each year; between 2001-2008 the transition probability was 12.1 per cent each year.

In the future an important extension will be to assess changes during the post-crisis period, when the 'Generation Rent' thesis gained broader prominence and when credit constraints were significantly tightened. At the time of analysis however, the limited number of waves of UK Household Longitudinal Survey data/Understanding Society (the replacement for the BHPS) available means direct comparison is not feasible. In addition, the post-crisis period saw unprecedented drops (and subsequent gains) in house prices in regionally differentiated ways and an abrupt increase in credit constraints, making the period difficult to compare with conditions 
during the long boom. Finally, divergences in housing policy between devolved administrations within the UK since around 2010 make it difficult to sustain a UK- or GB-wide analysis beyond the end of the long boom.

The binary dependent variable specifies whether an individual left the PRS for owner-occupation $(=1)$ or remained in the PRS $(=0)$. We estimate the probability of exiting the PRS between $t-1$ and $t$. Individual characteristics of tenure movers and non-movers are mostly measured at $t$ (the exceptions and the rationale for this are detailed below). This means we are able to capture changes in characteristics that have occurred between $t-1$ and $t$ that may influence tenure outcomes, such as partnering. Temporal and spatial data on housing and mortgage market conditions are also measured at $t$. There are 1,121 individuals and 2,948 person-years in model 1 for the 1990s, and 1,052 individuals and 3,035 person-years in model 2 for the 2000s.

There is a preference in tenure choice modelling for limiting sample membership to movers in order to avoid sample selection bias that occurs if non-movers and movers are mixed together (Painter, 2000; Raya and Garcia, 2012). For private renters this approach is less appropriate as moving is not consistently the result of individual renter choice. Rental agreements may end as a result of landlord decision-making over the sale of the rental property, the rental price or terms of the rental agreement. For this reason a model specification is preferred which includes all renters and controls for time spent within the tenure.

Data

The data used is from the British Household Panel Survey (BHPS). The BHPS is a large longitudinal survey which ran between 1991 and 2008 and which initially surveyed more than 10,000 individuals in around 5,500 households (the survey was superseded by a new panel survey, Understanding Society, in 2009). Individuals were surveyed on an annual basis collecting a wide range of information on employment, income, housing, household structure and health. An issue with any panel survey relates to the level of sample attrition. Of the original panel members in the BHPS, 78 per cent were still responding in Wave 4, 63 per cent in Wave 10 and 55 per cent in Wave 14 (Noah Uhrig, 2008). Attrition can result in biased estimates where it is associated with particular characteristics, in other words if it is non-random. Previous research demonstrates that while attrition rates are higher among movers in the BHPS, this is unlikely to significantly to affect the reliability of estimates (Rabe and Taylor, 2010).

Waves 4-18 of the BHPS are used in this analysis. Waves 1-3 are excluded because we cannot calculate a satisfactory measure of previous recent moves for these early years of the panel and 
because prior to this period house price information is not available at local level. The sample was drawn from original sample members (i.e., we do not include the extension samples) and tenure change is recorded on an annual basis ${ }^{\mathrm{ii}}$. The sample consists of individuals who were in the PRS at t- 1 and $t$, or who were in the PRS at $t-1$ and who move into owner-occupation at $t$. The sample is further limited to individuals within 'independent households', in other words we exclude those transiting to owner-occupation where this is lodging with parents or with a 'live-in' landlord/lady (this would exclude from the analysis for example students returning to the parental home after studies). These relationships were constructed using the BHPS household relationships grid. We do this as our concern is with the PRS to owner-occupation transition as part of a lifecycle event and as part of being or becoming an independent household.

We estimate a model in which the outcome of an individual exiting the PRS for owneroccupation is viewed as a function of: individual demographic and household characteristics; income and wealth; local housing market factors; regional location and mobility; and borrowing costs and availability of mortgage finance. The full list of variable names, definitions and sources is provided in Table 1 .

\section{Table 1 here}

\section{Explanatory variables}

House price growth since the early 2000s has been rapid and has widened geographic unevenness in house prices. It would be expected that higher local house prices would reduce PRS exits as the costs of entering owner-occupation grow. To assess the relationship between house prices and PRS exits we use data on local house prices from the Land Registry measuring the median values of transactions at Local Authority leveliii. These are matched to individual level data in the BHPS. House prices (and income data) are adjusted using the Retail Prices Index (RPI).

It is also possible that changes in career patterns, mobility and/or lifestyle choices have altered the rate at which individuals want to leave the PRS. Patterns of mobility may also respond to local house price trends, in other words households may choose to move to cheaper district to access owner-occupation. Here we focus on two aspects of mobility. Previous household mobility is linked with anticipated future mobility, which in turn makes people more likely to rent. We therefore include a binary measure of inter-regional mobility in the past two years (considering movement between the standard statistical regions). Second, we include a measure of inter-district mobility, specifically framing this around movement to a less expensive district 
(between $t-1$ and $t)$. In addition, we include a dummy variable for those living in southern regions, where house price rises have been most pronounced, on the basis that tenure choice and mortgage lending may be qualitatively different under markedly different housing market conditions.

Finally, we measure for the importance of duration in the PRS. Duration is measured as discrete as observations are only available on a yearly basis. Durations are calculated in two ways. First, as being directly observed, i.e., where a sample member is observed to enter the PRS from one wave to the next. This gives an accurate but incomplete measure, essentially limiting the sample to those entering the PRS from 1991 onwards. Secondly, for those sample members who are not observed entering the PRS (i.e. who started renting before the BHPS began) we use information on the year in which they moved into their current accommodation (and calculate duration to begin from this point). Combining these duration measures enables us to both maximise the available sample and to ensure the sample is representative of the tenure as a whole. Duration in the PRS may signal a number of different things. It may be linked to preference for the PRS over other tenures; this may derive from some particular advantage to the individual (such as greater geographic mobility). It may also reflect a preference against the upfront costs of moving into owner-occupation (which include legal, survey and taxation [Stamp Duty] costs). Duration itself may have a second-round effect on subsequent tenure preference, as people adapt or become resigned to continuing to rent.

\section{Control variables}

We include a range of control variables which influence the ability and propensity to enter owner-occupation. These are the core factors relating to life stage, family structure and financial position (Deurloo et al, 1997; Seko and Sumita, 2007; Spalkova and Spalek, 2014). Age is a central determinant of the likelihood of entering owner-occupation. In general, as age increases the probability of living in owner-occupied housing also increases. However, there is also likely to be a point at which age ceases to increase probability of exit and may reduce it. We include grouped age bands. Household situation and formation also affect housing choices; we include a measure of household type, capturing singles, couples, lone parents and living in shared accommodation.

The employment and financial characteristics of individuals and households exert a significant influence on housing transitions. Moving into owner-occupation is largely dependent on 
accessing mortgage finance (which is itself a function of household earnings and household wealth). For this reason we include measures of gross actual household income ${ }^{\mathrm{iv}}$ in the previous year as well as a measure for household wealth (also in the previous year). The household wealth variable is designed to proxy for the availability of a deposit to support accessing mortgage finance. As the BHPS only includes data on wealth at infrequent intervals, the wealth modules are not suited for inclusion here. We therefore estimate household wealth on the basis of household income from investments which is reported each year. This is then grossed up using long-term yields on investment incomes to estimate total wealth ${ }^{\mathrm{v}}$. We then transform this into a binary variable which takes the value of 1 in cases where the estimated wealth is equal to at least 5 per cent of median regional house prices and 0 if it is below. Evidence demonstrates that the incidence of parental help in purchasing first homes for young people grew significantly between the late 1990s and 2005; with rates of assistance tending to be higher in more costly regions (Tatch, 2007). There is no way of capturing the effect of this change from the data collected in the BHPS.

Expectations of future household incomes also influence the propensity to enter owneroccupation (Di Salvo and Ermisch, 1997; Zhou, 2011). We include a measure for occupation, where working in particular occupational groups may signify increased confidence in future earnings prospects. Professional occupations - Standard Occupational Classification groups 1-3 (managers, directors and senior officials; professionals; and associate professional and technical) are coded together to measure this ${ }^{\mathrm{vi}}$. Conversely being out of work is likely to reduce entry to owner-occupation so this is coded separately. Higher anticipated future costs of entry may increase exits to owner-occupation in the short-term. To account for this we include measures of house price expectations, measured as the percentage change in national house prices over the two preceding years; and, average mortgage rates and first-time buyer LTV ratio expectations, also using change over the period prior to the tenure choice.

An important influence on access to owner-occupation is the expansion or contraction of the availability of, and access to, credit to support house purchase, as well as changes to the cost of borrowing. It would be expected that any reduction in mortgage credit rationing would increase the rate of PRS exits to owner-occupation (Di Salvo and Ermish, 1997). We include the average Loan-to-Value (LTV) of first time buyers in each year, since higher prevailing LTVs in the mortgage market is likely to be associated with an increased likelihood of exiting the PRS as smaller deposits are required. It would also be expected that if the cost of borrowing falls this should also be associated with an increased likelihood of exiting the PRS for owner-occupation 
(Di Salvo and Ermish, 1997). We therefore include a measure of the cost of borrowing, based on the average rate charged by mortgage lenders in each year ${ }^{\text {vii }}$.

For all three of the main housing tenures, but particularly the two rental sectors, the availability of suitable, affordable and vacant properties in a given locality at a given point in time can be a significant constraint in households' housing search (Lee and Myers, 2003). We also therefore include a measure of the availability of privately rented accommodation at Local Authority level, based on the percentage of households living in the PRS, which has been interpolated from Census of Population years (1991, 2001 and 2011) to produce an annual local housing tenure series. The assumption here is that local areas with relatively larger private rented sectors will have a greater availability and choice of properties for private rent at any given time.

The analysis presented innovates in the use of a specially constructed panel data set of individuals combined with local area data, and data on credit and lending conditions, to assess changing housing transitions and the important influences on these. The length of the panel enables this assessment to be made over an extended period, and one which is critical in understanding the evolution of the British housing market. Critically the use of panel data also enables the influence of duration in the tenure to be captured. There are however a number of limitations to the analysis which are the result of data constraints. Household wealth is estimated rather than directly measured (although there is no reason to suggest any imprecision in measurement will be more pronounced in one time period than the other). Parental gifts or other forms of financial aid to access owner-occupation cannot be measured if they are given shortly before the move (this will slightly dampen down the impact of house price growth and mortgage credit rationing on PRS exits). There may also be other differences between individuals in the dataset which are not captured, for example around the extent to which to they prioritise home ownership over other elements of lifestyle (although at an aggregate level survey data suggests underlying attachment to home ownership is likely to be relatively consistent). Importantly, we also cannot account for the role of changes to different types of housing in influencing tenure transitions. For example, there may be a trade-off for individuals between renting a house or buying a flat. The extent and approach to weighing-up such trade-offs is an important area for future research.

\section{Results}


The results of the logit models are presented in Table 2 which reports the odds ratios and standard errors. The odds ratio describes the effect of a particular individual or household characteristic, or a change in covariate values (for example local house prices), on the likelihood of moving from the PRS into owner-occupation relative to remaining in the PRS.

\section{Table 2 bere}

The results from the 2000s differ in several respects to the 1990s in terms of the factors associated with exits from private renting to owner-occupation. First, the effect of local house prices on discouraging entries to owner-occupation becomes significant; suggesting house prices in some districts became unaffordable to many private tenants. In the 1990s the local cost of housing does not appear to have a strong influence on exits to owner-occupation - while the odds ratio for local (median) costs of housing is below one, it is not statistically significant. In contrast in the 2000s model the negative association between higher house prices and PRS exits to owner-occupation becomes statistically significant. This finding provides some support to the 'Generation Rent' thesis which posits rising house prices as a barrier to owner-occupation.

Second, the duration term has a weaker effect in the 2000s. In the 1990s we find that the duration effect becomes stronger with increasing duration so that by 5 years duration individuals become much less likely to leave the PRS for owner-occupation than those with shorter durations; with the odds ratio at 5 years and above duration being 0.18 . In the 2000s, the same broad effect is apparent but the change in the coefficient at duration in the PRS of 5 years or over is significantly smaller than for the 1990 s, with the odds ratio being 0.43 compared to 0.18 (the differences between the coefficients in the two models is statistically significant). On the one hand, tenants in the PRS are on average renting for longer than in the past and exit rates to homeownership declined - in this sense, the PRS is becoming more 'sticky'. On the other hand, after controlling for other factors, being a long-term renter is associated with a smaller reduction in the probability of becoming a homeowner than in the past - in this sense, the PRS is becoming less 'sticky', consistent with a greater willingness to delay homeownership.

Third, the link with residential mobility to lower cost districts disappears between periods. During the 1990s moving to a cheaper district was associated with an increased chance of entering over-occupation. By the 2000s there was no association between mobility to a cheaper district and entry to owner-occupation ${ }^{\text {viii }}$.

Although we have included age principally as a control variable, we note that people aged 16-24 are less likely to enter homeownership in the 2000s but there was no age effect after controlling 
for other factors in the 1990s. In the 1990s, 25-34 year olds and 35-44 year olds were no more likely to exit the PRS for owner-occupation that those aged 16-24. By the 2000s, 16-24s were significantly less likely to enter owner-occupation than 25-34 year olds and 35-44 year olds.

Finally, in the 2000s, being employed in a professional occupation has a significant effect on entering owner-occupation. This was not the case in the 1990s where the coefficients for professional and non-professional workers were similar. This is consistent with Coulter's (2016) analysis of social class and home ownership, reflecting stronger preferences for homeownership among professionals, greater confidence in future earnings, and/or credit scoring process for mortgage finance during the later period when house prices were rising faster.

As would be expected following existing literature, many of the other demographic and financial characteristic control variables are also significantly associated with PRS exit to owneroccupation. This includes being in a couple, and having greater income and wealth.

The national costs of borrowing do not appear to have had a strong influence on exits to owneroccupation during either period. In the 2000 s the mortgage rate is significant but is in the opposite direction than would be expected, with higher average variable rates associated with increased exit to owner-occupation. This effect appears to be driven by a single year, 2007. The lack of a cost of borrowing effect is surprising but may be partly a reflection of the measure used. This may not display sufficient variation over the period to detect an effect. Credit rationing is not significantly associated to the chance of exit in either period.

The per cent of households locally in the PRS is not significant in either model, suggesting that expansion of the PRS did not alter preferences or behaviour. Future expectations of mortgage interest rates or house prices are not significant in either model. We do not find pronounced regional effects between the Greater South East and the rest of Great Britain in either period. House prices in the Greater South East rose more quickly than in the rest of the UK in the period of analysis, but as we are controlling for district level house prices we capture house prices differences and change through this variable.

Taken together the findings indicate that the dynamics of the PRS to owner-occupation transitions and the role that the PRS played in the British housing market began to evolve during the 2000s. The findings are consistent with the view that the PRS served housing needs for longer-periods (and to later ages) but they also suggest a decreased incidence of moving districts to access owner-occupation vis-à-vis the 1990s. Given that long-term renting (more than five years) plays a weaker role in the 2000s in inhibiting transitions into homeownership, it would 
appear that private renters have shifted their strategy from one of moving to one of waiting. Another possibility, is that movements to cheaper districts became associated with an initial period renting followed by subsequent movement to owner-occupation (although re-running the models to include longer-term measures of district mobility yields consistent results). This finding is based on district mobility and does not capture, for example, neighbourhood mobility or quality trade-offs in accommodation standards within districts, which are important areas for further research. However the finding is suggestive of a changing a role for the PRS and raises a number of questions about underlying preferences, and decision making processes in housing pathways. The finding may in part reflect more widespread unaffordability, meaning there are less affordable districts to move to. It may also link with wider spatial concerns around the geography of employment as well as the nature of local housing markets in relation to access to good schools for example.

\section{Discussion}

This paper has assessed changes in the factors affecting household transitions from private renting to homeownership in the context of rapidly rising house prices.. The period covered by the analysis (1994-2008) is a critical one in the development of the UK housing market. House prices began to accelerate sharply, ushering in what is now widely described as a housing crisis. During this period, new patterns of tenure emerged as the PRS grew and owner-occupation declined (Kemp, 2015) against a background of increased investment in the PRS (Crook and Kemp, 2011) and declining residential mobility rates (Champion and Shuttleworth, 2017). However the role which these changes had on housing pathways and flows between the two tenures during this period is poorly understood.

The findings reported in this paper indicate that house prices have an increasing impact on reducing the probability of a private renter entering homeownership (research question 1) as emphasised in the 'Generation Rent' narrative. However, the dynamics of the rent to own transition shifted over this period in two ways: tenants opted to remain in the private rented sector for longer before entering homeownership (research question 2); and became significantly less likely to move to cheaper districts as a means of accessing owner-occupation (research question 3).

Longer-term renting, while still associated with a lower likelihood of exit, does not have the same association with remaining in the PRS that it once did. Conversely, short-duration renters in the 
2000s were less likely to enter homeownership than short-duration renters in the 1990s. These findings are consistent with a greater acceptance of long-term private renting and/or at least a greater willingness to delay homeownership. The findings on migration to districts with cheaper housing highlight the importance of spatial differences in housing markets and labour markets as shaping patterns of tenure transition (Hoolachan et al, 2017) - a plausible explanation is that many districts had become unaffordable for purchase by the end of the long boom, removing the advantage of moving.

As expected from existing literature, important determinants of moves from renting to owning are financial and demographic: being in a couple; being in a professional occupation (in the latter period); having a higher income; and having greater wealth. The effect of these factors was much the same in the 1990s as in the 2000s. However, the role of age changes, with being between 25 and 44 becoming a stronger predictor of entry to owner-occupation, reflecting the increase in age of the average first-time home purchaser over this period (Kemp, 2015).

\section{Conclusions}

Our findings reveal that as house prices rose to unaffordable levels for first-time house buyers in an increasing number of districts across the UK, even moving to a lower-cost district has ceased to be an effective strategy in securing homeownership. Length of time spent renting had less of an effect on entry to homeownership in the 2000s than in the 1990s, as tenants rent for longer.

It is possible that these findings in part reflect an underlying shift in preferences in favour of renting relative to owning, or at least a greater willingness to rent for longer, other things being equal. Evidence from the Australian rental market points towards individuals choosing to live in the PRS in their preferred location rather than move when they cannot afford to purchase property there (Hulse and Yates, 2016). This is also consistent with the message to 'wait then buy' preference reported from the British Social Attitudes Survey (Bramley 2012). In general, the transition from renting to owning a home may be gradually playing a slightly less significant role vis-à-vis other lifecourse-related events such as couple formation and starting a family, as lifecourses become more complex and sequencing of key life events more varied. The extent to which underlying housing tenure preferences may be changing is an important area for future research, internationally as well as in Britain. 
In common with other countries, Britain is experiencing a shift in the nature of the PRS, with the tenure becoming a longer-term (and perhaps permanent) home for increasing numbers of people (Easthope, 2014; Lennartz et al, 2015). Although the balance to which the patterns reflect delayed entry to owner-occupation or permanent absence from the tenure is unclear (Coulter, 2016) and is subject to future changes in both supply (housebuilding, landlord investment) and demand (demographic change, lifecourse trends and residential mobility) factors. What is clear is that strong aspirations for homeownership persist in the face of rapidly rising house prices, but with greater willingness to rent for longer and less use of residential mobility in order to secure homeownership. How the PRS can better meet the needs of long-term tenants and families is a key policy challenge, and governments across the UK may be able to learn from other countries where entry to homeownership occurs at older ages.

Our analysis has focused on the whole of Great Britain. However housing policy in the devolved nations has started to develop greater distinctiveness. In the future the role which devolved policy plays on the evolution of housing markets and patterns of tenure will be an important area of research. Housing is also an important theme within new approaches of devolution to British cities through a series of City Deals, Growth Deals and Devolution Agreements. Furthermore, underlying the national patterns which are described in the analysis, it would be expected that in different types of areas, experiences of housing pathways and transitions might be subject to different types of influences (Hoolachan et al, 2017).

Policymakers now widely acknowledge the importance of problems in the British housing market linked to affordability and quality, and new targets have been developed to increase housing supply. Issues of housing affordability (a central element of the crisis) are particularly pronounced in the South East (and especially acute in London). Reforms to taxation have also been enacted which makes landlord investment in the PRS less attractive in some circumstances. Significant changes have been introduced to private rented tenancies in Scotland to seek to increase security and safeguard affordability for tenants through the Private Housing (Tenancies) (Scotland) Act 2016. The 2017 UK Government housing White Paper seeks to provide a framework to significantly increase housing supply for owner-occupation as well as to increase investment in long-term rental properties. Evidence suggests a continuing underlying preference for owner-occupation remains, however our results also suggest propensity to move area in order to access owner-occupation from the PRS has declined and willingness to delay homeownership has increased. This highlights the critical importance of the geography of new housing supply 


\section{References}

Atkinson R (2000) The hidden costs of gentrification: displacement in central London Journal of Housing and the Built Environment, 15, 307-326.

Bitter C and Plane D (2012) Housing Markets, the Life Course, and Migration Up and Down the Urban Hierarchy. In Clapham DF, Clark W A V. and Gibb K (Eds) The Sage Handbook of Housing Studies. Sage: London, 295-312.

Bramley G (2012) 'Housing' in NATCEN British Social Attitudes Survey: 28. London: NATCEN

Champion T and Brown D L (2012) Migration and urban-rural population redistribution in the UK and US. In Shucksmith M, Brown D L, Shortall S, Vergunst J, and Warner M E (Eds), Rural Transformations and Rural Policies in the US and UK. New York \& London: Routledge, pp.39-57.

Champion T and Shuttleworth I (2017) Are People Changing Address Less? An Analysis of Migration within England and Wales, 1971-2011, by Distance of Move, Population, Space and Place, 23 (3), art. no. e2026, advance online publication.

Chowdhury R and Maclennan D (2014) "Regional house price cycles in the UK, 1978-2012: a Markov switching VAR", Journal of European Real Estate Research, 7:3, 345 - 366

Chung EC and Haurin DR (2002) Housing choices and uncertainty: The impact of stochastic events. Journal of Urban Economics, 52 (2), 193-216.

Clark WAV (2012) Residential Mobility and the Housing Market. In Clapham DF, Clark WAV. and Gibb K (Eds) The Sage Handbook of Housing Studies. Sage: London, 66-83.

Coulter R (2016) Social disparities in private renting amongst young families in England and Wales, 2001-2011. Housing, Theory and Society. DOI: 10.1080/14036096.2016.124511 
Crook, T. and Kemp, P.A., 2011, Transforming Private Landlords: Housing, Markets \& Public Policy.

Oxford: Wiley-Blackwell.

Deurloo RC, Dieleman FM, Clark WAV (1997) Tenure choice in the German housing market: A competing risks model. Tijdschrift voor Economische en Sociale Geografie, 88 (4), 321-331.

Di Salvo P and Ermisch J (1997) Analysis of the dynamics of housing tenure choice in Britain. Journal of Urban Economics, 42 (1), 1-17.

Easthope H (2014) Making a rental property home. Housing Studies, 29(5), 579-596

Hamnett C (2003) Unequal City: London in the Global Arena. London: Routledge.

Hatton T J and Tani M (2005), Immigration and Inter-Regional Mobility in the UK, 1982-2000. The Economic Journal, 115: 342-F358. doi: 10.1111/j.1468-0297.2005.01039.x

Hoolachan J, McKee K, Moore T and Mihaela Soatia A (2017) 'Generation rent' and the ability to 'settle down': economic and geographic variation in young people's housing transitions. Journal of Youth Studies 20(1), 63-78

Houston D and Sissons P (2012) The changing geography of privately rented housing in England and Wales. Urban Studies, 49(4), 795-819.

Hulse K and Yates J (2016) A private rental sector paradox: unpacking the effects of urban restructuring on housing market dynamics. Housing Studies DOI:

$10.1080 / 02673037.2016 .1194378$

Jones LD (1995) Testing the Central Prediction of Housing Tenure Transition Models. Journal of Urban Economics, 38 (1), 50-73.

Kemeny J (1995) From public housing to the social market: rental policy strategies in comparative perspective London: Routledge 
Kemp PA (2015) Private renting after the global financial crisis. Housing Studies 30(4), 601-620

Lee SW and Myers D (2003) Local housing-market effects on tenure choice. Journal of Housing and the Built Environment, 18 (2), 129-157.

Lennartz C, Arundel R and Ronald R (2015) Younger adults and homeownership in Europe through the global financial crisis. Population, Space and Place 22(8), 823-835

Malpass P and Murie A (1999) Housing policy and practice: 5 th Edition Hampshire: Macmillan

McKee K, Muir J and Moore T (2017) Housing policy in the UK: The importance of spatial nuance. Housing Studies 32(1), 60-72

Miles D (2004) The UK Mortgage Market: Taking a Longer-Term View. London: HMSO

Mok DKY. (2005) The life stages and housing decisions of young households: An insider perspective. Environment and Planning A, 37 (12), 2121-2146.

Muellbauer J and Murphy A (1997) Booms and Busts in the UK Housing Market. The Economic Journal, 107: 1701-1727. doi: 10.1111/j.1468-0297.1997.tb00076.x

Noah Uhrig S (2008) The nature and causes of attrition in the British Household Panel Survey ISER paper 2008-05

Painter G (2000) Tenure Choice with Sample Selection: Differences among Alternative Samples. Journal of Housing Economics, 9 (3), 197-213.

Rabe B and Taylor M (2010) 'Residential mobility, quality of neighbourhood and life course events' Journal of the Royal Statistically Society 173(3), 531-555

Ranney SI (1981) The Future Price of Houses, Mortgage Market Conditions, and the Returns to Homeownership, The American Economic Review, 71, (3), 323-333 
Raya J and Garcia J (2012) Which Are the Real Determinants of Tenure? A Comparative Analysis of Different Models of the Tenure Choice of a House. Urban Studies, 49 (16), 36453662.

Rhodes D (2006) The Modern Private Rented Sector. Coventry: Chartered Institute of Housing for the Joseph Rowntree Foundation.

Seko M and Sumita K (2007) Japanese housing tenure choice and welfare implications after the revision of the tenant protection law. Journal of Real Estate Finance and Economics, 35 (3), 357-383. Špalková D and Špalek J (2014) Housing tenure choice and housing expenditures in the Czech Republic. Review of European Studies, 6 (1), 23-33.

Tatch J (2007) 'Affordability - are parents helping?’ Housing Finance, 3, 1-11

Van Ham M (2012) Housing Behaviour. In Clapham, D.F., Clark, W.A.V. and Gibb, K. (Eds) The Sage Handbook of Housing Studies. Sage: London,.47-65.

Zhou J (2011) Uncertainty and housing tenure choice by household types: Evidence from China. China Economic Review, 22 (3), pp. 408-427. 
Figures and Tables

Figure 1: Real average house prices: United Kingdom, 1991-2013

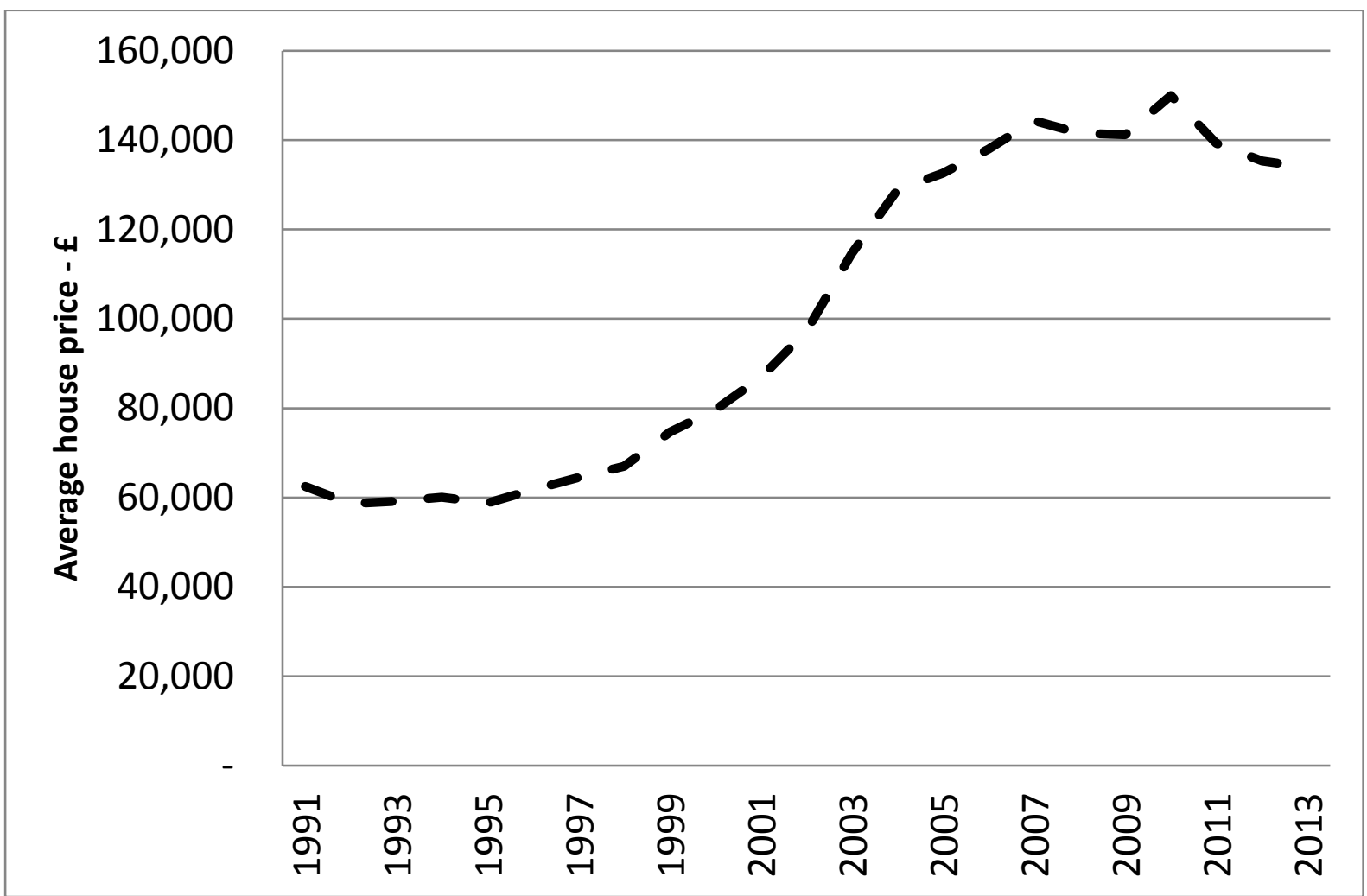

Source: Office for National Statistics, 2014; Simple average, adjusted by the annual all items Retail Price Index 
Table 1: Variables and definitions

\begin{tabular}{|c|c|c|}
\hline & Definition & Source \\
\hline Age & Age in bands - 16-24; $25-34 ; 35-44 ; 45$ and over & $\begin{array}{l}\text { British Household } \\
\text { Panel Survey }\end{array}$ \\
\hline Duration & $\begin{array}{l}\text { Duration in the PRS (years) in bands }-1-2 \text { years; } 3-4 \text { years; } 5 \text { years } \\
\text { and over }\end{array}$ & $\begin{array}{l}\text { British Household } \\
\text { Panel Survey }\end{array}$ \\
\hline District change & $\begin{array}{l}\text { Whether has moved districts between } t-1 \text { and } t \text {, and if move was } \\
\text { to more or less expensive district }\end{array}$ & $\begin{array}{l}\text { British Household } \\
\text { Panel Survey/ Land } \\
\text { Registry }\end{array}$ \\
\hline $\begin{array}{l}\% \text { Households } \\
\text { PRS }\end{array}$ & $\begin{array}{l}\text { Per cent of households in the PRS in the local authority of } \\
\text { residence }\end{array}$ & Census of Population \\
\hline Household & Household structure circumstances & $\begin{array}{l}\text { British Household } \\
\text { Panel Survey }\end{array}$ \\
\hline House prices & Median house prices in local authority of residence (natural log) & Land Registry \\
\hline Income & Total household income in the previous year (natural log) & $\begin{array}{l}\text { British Household } \\
\text { Panel Survey }\end{array}$ \\
\hline Region move & $\begin{array}{l}\text { Whether has made an inter-regional move in the two years prior to } \\
\text { observation }\end{array}$ & $\begin{array}{l}\text { British Household } \\
\text { Panel Survey }\end{array}$ \\
\hline Job class & $\begin{array}{l}\text { Whether an individual is employed in a non-professional } \\
\text { occupation or unemployed. Professional occupations defined as } \\
\text { Standard Occupation Classification } 1-3\end{array}$ & $\begin{array}{l}\text { British Household } \\
\text { Panel Survey }\end{array}$ \\
\hline Lives South & $\begin{array}{l}\text { Whether lives in the Greater South East (regions of London, } \\
\text { South East and East of England) }\end{array}$ & $\begin{array}{l}\text { British Household } \\
\text { Panel Survey }\end{array}$ \\
\hline $\begin{array}{l}\text { Mortgage } \\
\text { interest rate }\end{array}$ & $\begin{array}{l}\text { The average standard variable interest rate charged by mortgage } \\
\text { lenders }\end{array}$ & Bank of England \\
\hline $\begin{array}{l}\text { First time buyer } \\
\text { LTV }\end{array}$ & The median first time buyer loan-to-value ratio & $\begin{array}{l}\text { Council of Mortgage } \\
\text { Lenders }\end{array}$ \\
\hline Wealth & $\begin{array}{l}\text { Estimation of whether household has wealth equivalent to } \\
\text { mortgage deposit. Measured a } t-1\end{array}$ & $\begin{array}{l}\text { British Household } \\
\text { Panel Survey/ Land } \\
\text { Registry }\end{array}$ \\
\hline $\begin{array}{l}\text { Interest rate } \\
\text { expectations }\end{array}$ & $\begin{array}{l}\text { Mortgage rate expectations measured as the change in rates } \\
\text { between the two years prior to move }\end{array}$ & Bank of England \\
\hline $\begin{array}{l}\text { House price } \\
\text { expectations }\end{array}$ & $\begin{array}{l}\text { House price expectations measured as the change in national } \\
\text { median house prices between the two years prior to move }\end{array}$ & Land Registry \\
\hline
\end{tabular}


Table 2: PRS leavers (1) vs. PRS stayers (0): 1994-2000 \& 2001-2008, random effects, odds ratios

\begin{tabular}{|c|c|c|c|c|}
\hline & \multicolumn{2}{|l|}{ 1994-2000 } & \multicolumn{2}{|l|}{$2001-2008$} \\
\hline & Odds ratio & Std. Err. & Odds ratio & Std. Err. \\
\hline \multicolumn{5}{|l|}{ Age (Ref: 16-24) } \\
\hline $25-34$ & 1.231029 & 0.271287 & $2.342955^{* * *}$ & 0.56542 \\
\hline $35-44$ & 0.942849 & 0.242284 & $2.423711 * *$ & 0.665501 \\
\hline 45 and over & $0.29058^{* * *}$ & 0.084035 & 1.23721 & 0.343194 \\
\hline \multicolumn{5}{|l|}{ Duration in PRS (Ref: 1-2 years) } \\
\hline 3-4 years & $0.625733^{* *}$ & 0.107703 & $0.548982^{* *}$ & 0.096979 \\
\hline 5 years and over & $0.180721^{* * *}$ & 0.047772 & $0.434655^{* * *}$ & 0.07924 \\
\hline \multicolumn{5}{|c|}{ District change (Ref: Move to $>$ expensive district } \\
\hline No move & $0.204806^{* * *}$ & 0.051399 & $0.10838^{* * *}$ & 0.025922 \\
\hline Move to cheaper district & $2.183725^{*}$ & 0.668347 & 0.982302 & 0.283942 \\
\hline$\%$ households in PRS & 0.994977 & 0.01976 & 0.981123 & 0.01649 \\
\hline \multicolumn{5}{|l|}{ Household (Ref: Single adult) } \\
\hline Couple & $2.837198^{* * *}$ & 0.680981 & $2.352139 * * *$ & 0.508642 \\
\hline Lone parent & 1.845622 & 0.697999 & 1.449848 & 0.54569 \\
\hline Shared & 0.568194 & 0.184151 & 0.599404 & 0.199036 \\
\hline House prices $(\ln )$ & 0.595165 & 0.196954 & $0.529733^{*}$ & 0.132886 \\
\hline Income previous year (ln) & $1.609113^{* * *}$ & 0.18416 & $1.618135^{* * *}$ & 0.183309 \\
\hline Regional mover in past 2 years & 0.975584 & 0.190467 & 1.334947 & 0.273121 \\
\hline \multicolumn{5}{|l|}{ Job class (Ref: professional) } \\
\hline Non-professional & 0.948059 & 0.166943 & $0.668771 *$ & 0.111339 \\
\hline Not working & $0.396233^{* * *}$ & 0.091796 & $0.551747^{* * *}$ & 0.113698 \\
\hline Lives South & 0.825019 & 0.171547 & 1.092526 & 0.203527 \\
\hline Mortgage interest rate & 1.136667 & 0.176173 & $1.410124^{*}$ & 0.23771 \\
\hline First time buyer LTV & 0.886476 & 0.072192 & 1.083579 & 0.056376 \\
\hline Wealth & $1.555542^{*}$ & 0.269431 & $1.743326^{* *}$ & 0.29294 \\
\hline Interest rate expectations & 1.010273 & 0.049414 & 1.008358 & 0.017731 \\
\hline House price expectations & 1.006829 & 0.073093 & 0.920862 & 0.111566 \\
\hline Log likelihood & -776.56319 & & -861.36408 & \\
\hline LR model significance test & $\mathrm{X}^{2}(22) 177.69$ & & $\mathrm{X}^{2}(22) 240.86$ & \\
\hline Number of individuals & 1,121 & & 1,052 & \\
\hline Person years & 2,947 & & 3,034 & \\
\hline $\mathrm{R}^{2}$ (McKelvey and Zaviona) & & & & \\
\hline
\end{tabular}

$* * * \mathrm{p}<0.001, * * \mathrm{p}<0.01, * \mathrm{p}<0.05$ 


\footnotetext{
${ }^{i}$ We focus on Great Britain rather than the United Kingdom as comparable data is not available which covers Northern Ireland ii Running the models including the extension samples yields consistent results

iii Land Registry data are not available for 1994 so we use values 1995 and adjust these using data for regional house price change iv The previous year's data is used because of the potential that change in household situation and change in household income is a joint event

v Information is used on average annual returns on equities over the past twenty years taken from the Barclay's Equity Gilt Survey

vi The Standard Occupational Classification is based on the level of qualifications and skills required for particular occupational groups.

vii The average rate is imperfect since buyers tend to focus on immediate costs at which rates are often discounted (Miles, 2004). An alternative considered was to use the fixed rates associated with 95 per cent mortgages, however these data are not available in comparable form over the entire period of interest.

viii The analysis was also re-run including the local house price and mobility variables in separate models to assess any concerns about the association between them. The separately estimated models (including all other controls) yielded consistent results with the full models.
} 